
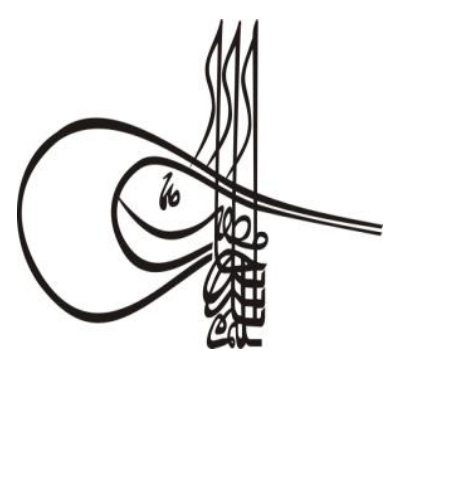

Received/Geliş: 29.07.2019

Go Report Dates/Rapor Tarihleri: Referee 1 (22.11.2019)-Referee 2 (27.11.2019)

\section{Turkish Studies \\ Language and Literature \\ Volume 14 Issue 4, 2019, p. 1707-1718 \\ DOI: 10.29228/TurkishStudies. 25896 \\ ISSN: 2667-5641 \\ Skopje/MACEDONIA-Ankara/TURKEY

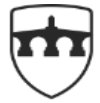 \\ INTERNATIONAL \\ BALKAN \\ UNIVERSITY \\ EXCELLENCE FOR THE FUTURE IBU.EDU.MK}

Research Article / Araştırma Makalesi

Article Info/Makale Bilgisi

This article was checked by iThenticate.

\title{
XVII.-XIX. YÜZYIL DOĞU TÜRK YAZI DİLİ İMLA GELENEĞİNDE MAHALLILLEŞME*
}

\author{
Serap ALPER*
}

\section{Öz}

Doğu Türk yazı dili, Moğol fütuhatından sonra Cengiz Han'ın çocukları tarafından kurulan Çağatay, İlhanlı ve Altınordu imparatorluklarının merkezinde XII-XIV. yüzyıllarda Eski Uygurca temelinde gelişerek XV. yüzyılda Emir Timur devrinde klasik bir mahiyet kazanmıştır. Klasik sonrası tabir edilen ve 1600-1921 yıllarını kapsayan devresinde de farklı siyasi dalgalanmalar ve değişikliklere paralel olarak geniş bir sahada farklı kültür merkezlerinde işlenmeye devam etmiştir. XIX. yüzyıl ortalarına kadar tüm Orta Asya'da edebi dil ve kültür dili olarak kullanılarak XX. yüzyıldan itibaren çağdaş Türk lehçelerinin ortaya çıkması şeklinde bir gelişim göstermiştir.

Doğu Türk yazı dilinde XV. yüzyıla kadar özellikle Oğuz-Kıpçak unsurlarının karışmasıyla birtakım ayrılıklar görülse de, esas değişim klasik yap1 kurulduktan sonra XVI.-XVII. yüzyıldan itibaren yerel unsurların yazı diline daha yoğun sirayetiyle başlamıştır. XVII. yüzyıldan itibaren verilen eserlerde klasik yazı dili özellikleri ve yerel unsurların bir arada kullanıldığı görülmektedir. Bu dönem metinleri henüz layıkıyla işlenmemiş olup diyalekt atlasları tam tespit edilmemiştir.

Doğu Türkistan'da yaşayan Uygurlar da XV. yüzyıldan XX. yüzyıla kadar Doğu Türk yazı diliyle sayısız eser kaleme almışlardır. XIX.-XX. yüzyıllarda misyonerler, gezginler ya da araştırıcılar tarafından çeşitli șekillerde farklı ülkelere götürülen bu eserler bugün İsveç, Rusya, İngiltere, Almanya ve başka ülkelerde çeşitli kütüphanelerin koleksiyonlarında bulunmaktadır. Son zamanlarda eserler üzerine Türkiye, İsveç, Çin, Özbekistan ve başka yerlerde çalışmalar yapılmaktadır. Makalemizin amacı, Uygurlara ait bu geniş külliyattan

* 21-23.09.2017 tarihinde Nevşehir Hacı Bektaş Veli Üniversitesi’nde düzenlenen Uluslararası Ípek Yolu Akademik Çalışmalar Sempozyumu'unda sunulan bildirinin genişletilmiş şeklidir.

** ID Dr. Öğr. Üyesi, Mimar Sinan Güzel Sanatlar Üniversitesi, E-posta: alperserap@ gmail.com 
üzerinde çalıştığımız risale, tezkire ve edebi metin örneklerinden hareketle Doğu Türkçesinin klasik sonrası döneminde imlada görülen mahallileşme ölçütlerini tespit etmek, farklılıkları dikkatlere sunmak ve sonraki çalışmalara zemin hazırlamaktır.

Anahtar Kelimeler: Doğu Türkçesi, klasik sonrası dönem, imla, mahallileşme

\title{
LOCALIZATION OF ORTHOGRAPHY TRADITION IN 17TH- 19TH CENTURY EASTERN LITERARY TURKIC
}

\begin{abstract}
Eastern Literary Turkic was established after the invasion of the Mongols, in the centre of Chaghatai, Ilkhanid and Golden Horde empires which were founded by the children of Cenghis Khan in the 12th-14th century and gained a classical character in the time of Amir Timur in the 15 th century. In the post-classical period in-between 1600-1921, it continued to be processed in different cultural centres of widespread geography in variable political fluctuations. It was used as literary and culture language in Central Asia till the middle of the 19th century, and has evolved into the emergence of contemporary Turkic dialects beginning from the 20th century.

Although some distinctions in the eastern Turkish literary language can be observed with the influence of Oghuz-Kipchak elements up to the 15th century, the major transformations begins after the establishment of the classical structure by the increasing spread of the local elements over the literary language of the 17 th century. The both usage of the classical literary language features and the local elements are observable in the writings after this century. The texts of this period have not been fully researched yet, as their atlas of dialects have not been entirely identified.

Uighurs, living in East Turkestan, have received numerous writings in Eastern Turkic in-between the 15th and 20th centuries. These writings were taken away to various countries by missionaries, travellers or researchers, are nowadays in the collections of various libraries in Sweden, Russia, England and Germany. The writings are recently being studied in Turkey, Sweden, China, Uzbekistan and elsewhere. The purpose of our article is to identify the criteria of localization in the postclassical period of the Eastern Turkic by considering the distinctions in the pamphlets, tezkires and literary texts that we have focused on within this broad collection of Uighurs.
\end{abstract}

\section{STRUCTURED ABSTRACT}

Eastern Literary Turkic was established in the center of Chaghatai, Ilkhanid and Golden Horde empires which were founded by the children of Cenghis Khan in the 12th-14th century and gained a classical character in the time of Amir Timur in the 15th century. 
The representatives of the Turkish written language, which continued its presence in two main branches since the 15th century, were Ottoman Turkish as Western Turkish written language and Chaghatai Turkish as Eastern Turkish written language. Chaghatai Turkish which became the only written language in Eastern Turkisness area, continued to be processed in different cultural centers by many poets in the postclassical period.

The emergence of contemporary dialects from the Eastern Turkish which continued to exist as a common written language to the east of Turkishness world until the 20th century, has manifested itself by the influence of the dialects of different Turkish clans on the written language at manuscripts. It is possible to identify the changes in phonetics and morphology as well as vocabulary.

In this edict, we tried to exemplify the localization on orthography through the following manuscripts written in-between the 16th- 19th centuries in important commercial and cultural centers such as Kashgar, Hoten, Yarkend which remain in the Uighur Autonomous Region of the People's Repuclic of China. This manuscripts are;

- Three pamphlets called Risale-i Aşfezlik, Risale-i Kaçacılık, Risale-i Sabungerlik;

\section{Imam Cafer \\ Two tezkires called Ziyaü'l-Kulüb and Tezkire-i Hazret-i}

A mesnewi called Leyli vü Mecnun written by Ömer Baki

Through our studies on this Turkish manuscripts with Arabic alphabet which written in the same period, in the same region, we have identified four features that will support localization in written languages. This features are:

1. Spelling of the vowels in loan words: While normal lenght vowels are not written in Arabic written language, in this manuscrits its possible to see written or not written examples of normal length vowels like Ø̄ālim (LM64b/9; عالي) A. عاليم), bereket (RS12b/7; RA10b/1, 14b/3,

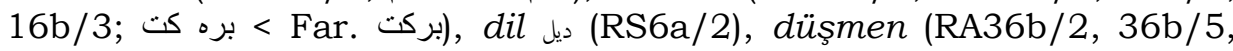

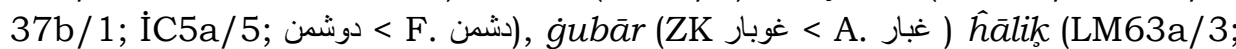

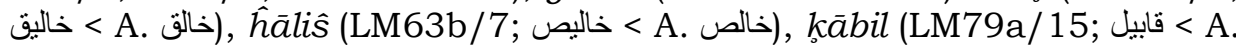

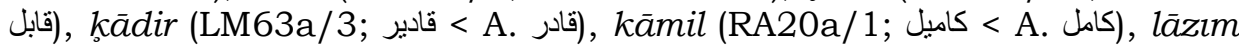

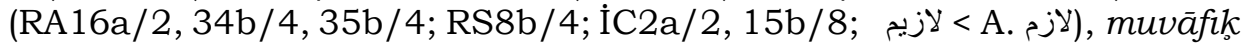

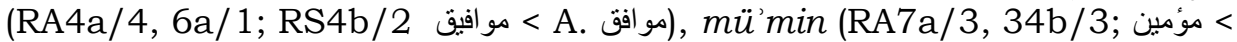
A. مؤمن) etc.

2. Not to write long vowels in loan words: This feature, which has interpreted as a scribe's fault, is a data that will illuminate the process of the change of long vowels in Uighur Turkish.

3. Spelling of the closed e: This vocal is generally written with ya (ى), but in Leyli vü Mecnun we see it written with elif (').

4. Spelling of bol-: In this manuscripts we see this verb written in three different ways: بول: بول aب ال بل , The most interesting of this writting skills is spelling of elif with vav (بول). Than we found an other example tol- (توال). We examine this subject with its examples from 
manuscripts of previous periods to illuminate the transition process of Uighur Turkish.

As a result, efforts to establish criteria to determine time and field distinction in history of language has been weak fort he post- classical Eastern Turkish, due to the fact that the manuscripts have not been fully revealed.

We tried to determine the distintions in writings from the classical Eastern Turkish through using manuscripts which written in different centuries but on common geography and with common written language.

In Eastern Turkish, which has existed as a common written language in the eastern part of the Turkishness world until the 20th century, produced manuscripts which shown the characteristics of the dialects of different Turkish clans on phonetics and morphology as well as vocabulary. The localization tendencies on orthography, important in that it shows the reflexion of spoken language to the written language in the process of emergence of the new written languages from the common Eastern written language.

New studies on new manuscripts or the studies on existing manuscripts by approaching from this perspective will present serious materials about the localization.

Keywords: Eastern Turkic, post-classical period, orthography, localization.

\section{Giriş}

"Moğol istilasından sonra Cengiz çocukları tarafından kurulan Çağatay, İlhanlı ve AltınOrdu imparatorluklarının medeni merkezlerinde XIII.-XIV. asırlarda inkişaf eden ve Timurlular devrinde bilhassa XV. asırda klasik bir mahiyet alarak, zengin bir edebiyat yaratan edebi orta Asya lehçesi” (Köprülü, 1988: 270b) şeklinde tanımlanan Doğu Türk yazı dili (daha yaygın adlandırmayla Çağatayca), Moğol akınları sonucunda mahalli lehçeler ve Oğuz-Kıpçak unsurlarının karışmasıyla birtakım ayrılıklar gösterse de Emir Timur devrinde Maveraünnehir, Harezm ve Horasan sahalarında büyük önem kazanarak klasik bir dil mahiyeti almaya başlamıştır.

Türk dilinin XV.-XX. yüzyıllar arasındaki edebi lehçesi olan Doğu Türk yazı dilinin dönemleri konusunda yapılan birçok tasnif içinde bugün daha çok kabul gören Eckmann'ın tasnifine göre bu edebi Türk dili üç döneme ayrılır:

- Klasik Öncesi Çağatayca Devri (XV. yüzyıl baş1-1465): Ali Şir Nevayi'nin ilk divanının tertip tarihi olan 1465 'ten önceki şair ve yazarların eserlerinin oluşturduğu dönemdir.

- Klasik Çağatayca Devri (1465-1600): Nevayi ile çağdaşlarının dönemidir.

- Klasik Sonrası Çağatayca Devri (1600-1921): Klasik Çağatayca dönemini izleyen dönemdir (Eckmann, 1988, s. XIII-XIV).

XV. yüzyıldan itibaren iki ana kol halinde varlığını sürdüren Türk yazı dilinin temsilcileri, Batı Türk yazı dili olarak Osmanlı Türkçesi ve Doğu Türk yazı dili olarak Çağatayca olmuştur. Doğu Türklük sahasında tek yazı dili olma özelliği kazanan Çağatayca, klasik sonrası döneminde de pek çok şair tarafından farklı kültür merkezlerinde işlenmeye devam etmiş ve son döneminde Eckmann'ın belirttiği gibi "bu dönemde bir yandan özellikle Nevâyî dikkatli bir biçimde taklit edilmiş diğer yandan da Özbek unsurlarının etkisi olmuştur." (Eckmann, 1988, s.XIV). 
XVII. yüzyılda yazılmış olan ve Eckmann'ın tasnifine göre klasik sonrası dönem metinleri içinde bulunan Şecere-i Terâkime üzerinde çalışan Kargi-Ölmez, Kononov'un eser için "Klasik Çağatay edebi dilinin Özbek lehçesi ile karışmış nümunesidir. Klasik Çağatayca ile Ebülgazi'nin gerek Şecere-i Türk'ü gerek Şecere-i Terâkime nüshaları mukayese edilirse görülür ki XVIIinci asırdan itibaren klasik Çağatayca, yaşayan Türkmen ve Özbek lehçelerinin tesirile eski kuvvetini kaybetmiştir." ifadesine de dayanarak eserin Çağatay Türkçesi ile yazıldığını ancak yer yer Oğuzca, Özbekçe ve Kıpçakça özelliklere rastlandığını belirtir (K.-Ölmez 1996: 31). Eserin kelime kadrosunda Arapça, Farsça ve Çağatayca sözcüklerin yanı sıra Çağataycada bulunmayan Türkmence ve Özbekçe sözcüklerin bulunduğunu da ekler (K.-Ölmez 1996: 34). Şecere-i Terâkime'nin dili ile klasik dönem metinlerinin dilini karşılaştırarak söz varlığının yanı sıra ses ve biçim bilgisi özelliklerinde etkin olan mahallileşme eğilimini, Eckmann'ın klasik dile Türkmen ve Özbek unsurlarının girmesi yoluyla gerçekleştiği yolundaki kanaatini destekler şekilde dile getirir.

Son zamanlarda İsveç, Rusya, İngiltere ve Almanya'da çeşitli kütüphanelerin koleksiyonlarında ${ }^{1}$ Uygur sahasına ait metinler tespit edilmiş ve bu metinler üzerinde Türkiye, İsveç, Çin, Özbekistan ve başka yerlerde çalışmalar yapılmıştır. Bizim de birkaçı üzerinde çalışma imkanı bulduğumuz bu metinler, XVII.-XX. yüzyıllarda Kaşgar, Yarkent, Hoten çevresinde ortaya konan ve Yeni Uygurca'nın yazı dilinde kendini göstermeye başladığı eserlerdir. Bunlardan dil ve imla açısından incelendiğimiz metinler, Eckmann'ın görüşüne ek olarak klasik Doğu Türkçesinin XVII. yüzyıldan itibaren sadece Türkmen ve Özbek lehçelerinin tesiriyle mi eski gücünü kaybettiği sorusunu irdelememize neden olmuştur. XX. yüzyıla kadar Türk dünyasının doğu kanadında ortak yazı dili olarak varlığını sürdüren Doğu Türkçesinden çağdaş lehçelerin ortaya çıkışı, XVII. yüzyıldan itibaren eserlerin vücuda getirildiği bölgelerdeki Türk boylarının ağızlarının bu yazı diline sirayetiyle kendini göstermiştir. İlk sirayetler olarak söz varlığının yanı sıra ses ve biçim bilgisinde görülen değiş̧iklikleri imlada tespit etmek mümkündür. İmladaki mahallileşmeyi, üzerinde bizzat çalıştığımız Çin Halk Cumhuriyeti'ne bağlı Uygur Özerk Bölgesi'nde kalan Kaşgar, Hoten, Yarkent gibi önemli ticaret ve kültür merkezlerinde XVI.-XIX. yüzyıllar arasında yazılmış olan aşağıdaki eserler üzerinden örneklendirmeye çalışacağız.

\section{2. İncelenen Eserler}

2.1. Meslek risaleleri ${ }^{2}$ : İsveç, Rusya, İngiltere ve Almanya'da çeşitli kütüphanelerin koleksiyonlarında tespit edilen ve dil özelliklerine göre XVII.-XIX. yüzyıllarda Doğu

\footnotetext{
${ }^{1}$ Eserlerin farklı ülkelere dağılmasının birden çok sebebi olup bunların başında siyasi sebepler gelmektedir. Yine misyonerlik amaçlı gelen yabancıların ilgisi ya da Doğu Türk dili ve edebiyatı üzerine çalışan yabancı Türkologların şahsi ilgileri veya çalıştıkları üniversite kütüphanesiyle yürüttükleri veri toplama faaliyetlerinin yanı sıra çalınma gibi etik dışı nedenlerle de bu eserlerin yayılmış olduğu görülmektedir. Dünyanın üçüncü büyük Doğu Türkistan yazmaları koleksiyonu olan İsveç’teki Lund Üniversitesi kütüphanesinde bulunan yazma eser koleksiyonu çoğunluğu İsveçli diplomat ve filolog Gunnar Jarring'in Doğu Türkistan'dan getirdiği ve 1982 yılında bağışladığı Çağatay, Özbek ve Uygur Türkçesi ile yazılmış yazma eserler ile bir kısmı İsveçli misyonerler tarafından bağıșlanan, satılan veya üniversite kütüphanesi tarafından satın alınan yazma eserlerden oluşmaktadır. Jarring Koleksiyonu için bkz. Gunilla TÖRNVALL (2014), "Hoten ve Kaşgar'dan: Gunnar Jarring ve Jarring Koleksiyonu", Çev.: Serkan ÇAKMAK, Uluslararası Uygur Araştırmaları Dergisi, Sayı: 4, s. 103-111. St. Petersburg Rusya Bilimler Akademisi Doğu Bilimi Enstitüsü Kütüphanesinde divan, tezkire ve risaleler başta olmak üzere çok sayıda el yazması vardır. Fransa İlimler Akademisi Kütüphanesi ile Şincan Uygur Özerk Bölgesi Eski Eserler İşhanesi ve İktisadi Fenler Akademisi Kütüphanesi de el yazması eserlerin bulunduğu merkezlerdir.

${ }^{2}$ İsveç Lund Üniversitesi Jarring Koleksiyonu içindeki XVI. ve XX. yüzyıllar arasında farklı tarihlere ait olan yazma eserler arasında bulunan demircilik mesleğine ait bir risale Ümit EKER ve Ünal ZAL tarafindan çeviri yazı alfabesine aktarılmıștır. Nevşehir Hacı Bektaş Veli Üniversitesi Bilimsel Araştırmalar Projesi Birimi tarafından desteklenen Çağatay Türkçesiyle Yazılan ve Geleneksel Meslekleri Konu Alan Risalelerin Araştırılması, İncelenmesi ve Yayımlanması başlıklı proje ile Çin'de, İsveç’te ve Rusya'da bulunan meslek risalelerinden Risāle-i Dehkānçıllk, Risāle-i Harrātllk, Risāle-i Aşfezlik, Risāale-i Nemed-māllık Adem Öger ve Recep Tek'in editörlüğünde; Risāale-i Tegürmendçilik ve Risāle-i Kassāblık Adem Öger ve Filiz Kılıç editörlüğünde yayımlanmıştır. Yine Lund Koleksiyonunda bulunan Rengrizlik Risalesi, Adem ÖGER ve Nuriman Abdurreşit KAŞGARİ tarafından çalışılmıştır: “Uygurlarda Risalecilik Geleneği ve Rengrizlik Risalesi”, Türk
} 
Türkçesinin klasik sonrası devrinde Kaşgar, Yarkent, Hoten gibi önemli ticaret ve kültür merkezlerinden birinde yazıldığını düşündüğümüz birçok meslek risalesinden üzerinde çalıştı̆̆ımız üç risaleyi Risale-i Sabungerlik (RS), Risale-i Kaçacılık (RK), Risale-i Aşfezlik (RA) imla açısından inceledik. Söz konusu risaleler, ele aldıkları mesleğin öncülerinin, geçmişinin, ilkelerinin dini değerlerle bütünleştirilerek, genellikle sorucevap yoluyla anlatıldığı didaktik eserlerdir. Mesleğin ne olduğu, nasıl icra edildiğinden ziyade mesleğe yeni giren kişiye meslek ahlakını anlatması bakımından her meslek adayının anlayabileceği bir dil ve üslupla yazıldığı için yerel unsurların kendini gösterdiği metinlerdir.

2.2. Ziyaü'l-Kulub (ZK) tezkiresi: Eser, Şeyh Seyyid Kasânî'nin (Mahdum-1 Âzam) oğlu ve XVI. yüzyılda Doğu Türkistan'ın en meşhur sufilerinden Hoca İshak'1 konu edinen bir tezkiredir. Çelik, Hoca İshak'ın Kazaklar, Kırgızlar, Kalmuklar ile diğer kabile ve halklardan çok sayıda insanı Müslüman yaptığını anlatan bu tezkire sayesinde XVI. yüzyılda kabilelerin yerleşim alanlarını tespit etmenin nispeten mümkün olduğunu belirtmiştir (Çelik 2012: 75). Her sayfada 11 satırdan oluşan ara ara Farsça beyitler bulunduran mensur tezkire, baştan ve sondan eksik olup 80 varaktan oluşmaktadır. XVI. yüzyılda kabilelerin ağız özelliklerinin yazı diline yansıdığı örnekleri vermesi açısından önemlidir ${ }^{3}$.

2.3. Tezkire-i Hazret-i İmam $\mathrm{Ca}^{\text {' }}$ fer (İC): Her ne kadar yazmanın başında bu şekilde isimlendirilmiş olsa da Uygurlar arasında meşhur olan Dört İmam Efsanesi'ni konu edinen ve XIX. yüzyılda Doğu Türkçesiyle kaleme alınmış olan bu eserin birçok mensur nüshası olmakla birlikte, şimdilik tespit edebildiğimiz iki manzum nüshası üzerinde yaptığımız çalışma ağız özelliklerinin imlaya etkisini göstermesi bakımından önemlidir ${ }^{4}$.

2.4. Uygur destan şairi Ömer Baki "nin Hamse-i Nevayî adlı eserini oluşturan iki hikâye Leylî vü Mecnun (LM) ve Ferhad ü Şirin (FŞ): Her ne kadar "hamse" olarak adlandırılmışsa da sadece iki hikâyeyi barındıran ve XVIII.-XIX. yüzyıllara tarihlendirebildiğimiz eser, tam da Eckmann'1n, klasik sonrası dönemde bir yandan özellikle Nevayi'nin dikkatli bir biçimde taklit edildiği diğer yandan da Özbek unsurlarının etkisinin olduğu (Eckmann 1988: XIV) görüşünü destekleyen, Yeni Uygurca unsurları da barındıran bir eserdir.

\section{3. İmlada Mahallileșme Örnekleri}

Klasik sonrası döneme ait olan ve aynı bölgede yazılan bu metinlerin imla açısından klasik dönem metinlerinden ayrılan özelliklerinin tespit edilmesi konuşma dilinin yazı diline nasıl aksettirildiğini gösterecektir. Bu bağlamda eserlerde ortaklık gösteren imla hususiyetlerini şu şekilde ele almamız mümkündür:

\footnotetext{
Dünyası Dil ve Edebiyat Dergisi, S. 41, 2016, s. 10-49. Konya Bölge Yazma eserler Kütüphanesinde bulunan Çağatayca iki meslek risalesi Fatih ERBAY tarafından çalışılmıştır: "Çağatay Türkçesiyle Yazılmış İki Risâle: Risâle-i Çârvâdârçılık ve Risâle-i Dihkânçılık”, Modern Türklük Araştırmaları Dergisi, Cilt: 9, Sayı: 4 (Aralık 2012), s. 103-124. Urumçi'de bir sahafta bulduğu bir meslek risalesi üzerinde de Semra ALYILMAZ çalışmıştır: Risâle-i Mûze-dûzluk (İncelemeMetin- Dizin), Elik Yayınları, Ankara 2011.

${ }^{3}$ Bir proje dahilinde eser üzerinde çalışmaktayız. Metnin yazı çevrimi ve Türkiye Türkçesine aktarımı tamamlanmış olup neşre hazırlanmaktadır.

${ }^{4}$ Eser, tarafımızdan çalışılmaktadır.

${ }^{5}$ XVIII. yüzyılın sonu XIX. yüzyılın başında yaşamış Uygur destan şairi Ömer Baki’nin bilinen iki eseri bulunmaktadır. Ferhad ü Şirin ve Leylî vü Mecnun adlı mensur-manzum yazılan bu iki eser Hamse-i Nevayî adını verdiği eserde bir araya gelmiştir. Leylî vü Mecnun adlı eser tarafımızca, Ferhad ü Şirin ise Fatih BAKIRCI tarafindan çalışlıp neşredilmiştir (2016).
} 
3.1. Alıntı kelimelerde normal uzunluktaki ünlünün gösterilmesi:

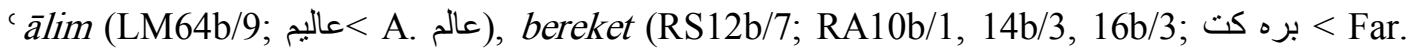

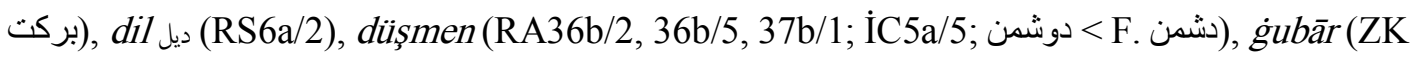

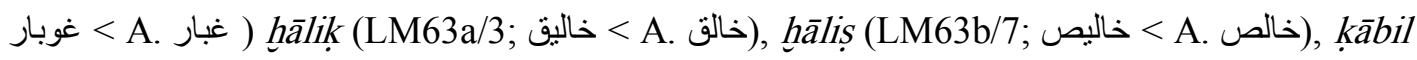

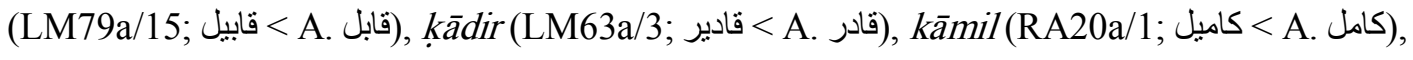

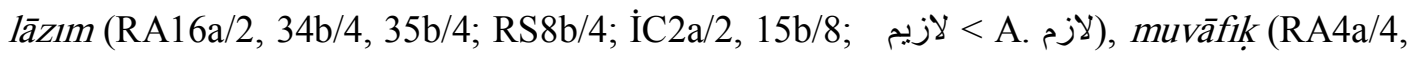

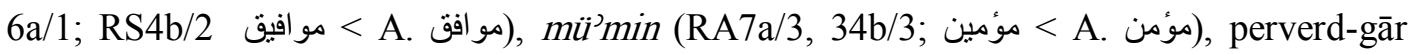

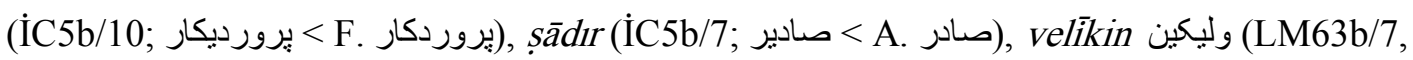
$68 \mathrm{~b} / 2)$ gibi.

“Ana Türkçede ilk hecedeki birincil ünlü uzunluklarını en çok ve en iyi şekilde korumuş olan dil Türkmencedir." diyen Tekin, belirli sözcüklerin şu ya da bu Türkmen lehçesinde farklı şekilde söylenmesinin uzun ünlüleri tesbit işini bir hayli güçleştirdiğini belirttikten sonra, hāāissa, hătịira, tecrỉbe, hāaliṣ, mınāsīp alıntı kelime örneklerini vererek özellikle sözcügün orta ve son hecelerinde daha çok rastlandığını belirttiği bu hadiseyi yakıştırma yoluyla oluşturulmuş analojik ünlü uzunluğu diye nitelemiştir (Tekin 1995: 64).

Alıntılarda karşılaşılan orijinal yazımlarından farklı normal uzunlukta yazılıp Türk yazım geleneğine yaklaşan bu meyli Türkçeleştirme çabası olarak değerlendiren Seyhan'a göre, "Karahanlı, Harezm, Kıpçak ve Çağatayca'nın ilk dönemlerinde alıntılar esas olarak orijinal imlalarıyla tespit edilmiş; ancak harekelerle bunlarda sonda çift ünsüzlerden birinin düşürülmesi, farklı ünsüz birlikleri arasında ses türemesi şeklinde Türkçeleştirme sınırlı olarak meydana gelmiş, Kuman, Kıpçak ve Çağatay devirlerine geçtikçe bu değişmeler daha geniş ve düzenlilik göstermeye başlamıştır" (Seyhan 2004: 2704). Orta Türkçe dönemi eserlerinden Nehcü'l-Feradis ve İrşadü'l-Müluk'ta da gördüğümüz bu yazımları, konuşma dilinde yakıştırma yoluyla oluşturulmuş analojik ünlü uzunluğunun imlaya aksettirilerek imlada sözcügün telaffuzunu belirtme çabası olarak değerlendirebiliriz.

3.2. Alıntı kelimelerde uzun ünlünün yazılmaması:

RS'de ervāḥ kelimesi 2 kez orijinal imlası ile yazıldıktan sonra RS6b/1'de اروح şeklinde, șābūn kelimesi 8 kere doğru imla ile yazıldıktan sonra RS7b/6, 8a/7, 8b/5, 12a/4, 12b/2ve 12b/6'da صبون şeklinde, tekbïr kelimesi 11 kez doğru imla ile yazılıp RS8b/3, 9a/4, 13b/4'de

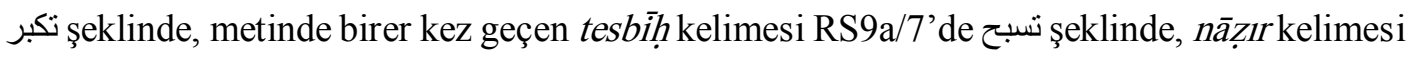
RS11b/3'te نظs şeklinde yazılmıştır.

Bu ve buna benzer yazımlar bir tutarlılık arz etmediği için müstensihten kaynaklanan hatalar olarak görülmüştür. Fakat Sabunculuk Risalesi'nde, sabun kelimesinin 8 kere orijinal imlası ile 6 kere ilk hecedeki ünlüsü gösterilmeden yazılmasındaki istatiksel yakınlık, bu durumun da sözcügün ilk ünlüsünü kısa söyleyen bir ağzın bu özelliği yazıma yansıttığı şeklinde değerlendirilebilir. Bunlar, uzun ünlülerin Yeni Uygurcadaki değişimiyle ilgili süreci aydınlatacak veriler olup bu dönem ve saha eserleri üzerinde yapılacak çalışmalarla konu müstensihten kaynaklı yazım hatası olarak görülmekten çıkacaktır.

3.3. Kapalı e (è)'nin gösterimi: Arap harfli Türkçe metinlerde ilk hece /e/ ünlüsünün düzenli bir şekilde yâ ile yazılması ve özellikle Nehcü'l-Feradis'te bu sesin özel bir işaretle (üstünlü 
yâ) ile yazılması, bize bu dönemde de /e/ ile /i/ arasında bir sesin varlığını göstermesi bakımından önemlidir. Bu ses, bugün de özellikle Oğuz sahasında Azerbaycan Türkçesi ve Türkmencede, hatta Türkiye Türkçesi ağızlarında; Doğu Türklük sahasında özellikle Özbek Türkçesi ile Yeni Uygur Türkçesinde ve diğerlerinde de varlığını koruyan kapalı e /è/ ünlüsüdür.

Eski Türkçe döneminden beri gerek tarihi gerekse çağdaş Türk lehçelerinde kullanılan bu sesin gösterimi için inceleme konusu olan metinlerde özel bir işaret kullanılmamakla birlikte umumiyetle yâ $\varsigma$ ile gösterilmiș ya da hiç gösterilmemiștir. Bugün bu sesin çeviriyazı metinlerde nasıl gösterilmesi gerektiği hususunda çeşitli görüşler bulunmaktadır ${ }^{6}$. Çalışmalarımızda yazım dikkate alınmaksızın ses değerlerini gözeterek /è/ kullanmayı tercih ettik. Burada üzerinde durmak istediğimiz yazım hususiyeti kapalı e'nin LM'de dört yerde elif ile gösterilmesidir ki dikkat çekicidir ve üzerinde durulmamıştır:

Mecnūn hem nāme bitip Zeyd'ning kolıg̉a bèrdi (LM76a/4) cümlesinde bèrdi باردى şeklinde;

Émdi sizler yanıp barınglar, dẻp ruhṣat bèrip yandurdı (LM81a/5) cümlesinde bèrip باريب şeklinde;

$\mathrm{Bu}$ yètip bard1 (LM65b/15) ve

Mecnūn āhỉ tartıp mest tève dèk bazulap yètip kèldi(LM84a/12) cümlelerinde yètip ياتيب şeklinde yazılmıştır.

FŞ'de ise 75 kere geçen bèr- fiili 14 kere bar- olarak, 46 kez geçen yèt-kelimesi bir kere yat- olarak ve 4 kere geçen bèri kelimesi bir kere barı olarak elif (') ile yazılmıştır:

'ālemġa rūşenlik bèrür (FŞ14b/7)

Hֵıżrī ‘aleyhi’s-selām ta 'līm bẻrip yolg̀a saldılar (FŞ14b/12)

Şāfūr pāklık ve hūbluḳ birle cevāb bèrür èrdi (FŞ30a/9)

bu vāḳı lar Ḩıṭāy țarafige yètip haḳanġa ėşitilse (FŞ44a/4)

Bir ' arżımız ol kim bu şehr nęçe vaḳtdın bèri nā-ḩayl bolup kişi çıka'lmadı (FŞ56a/14)

\footnotetext{
${ }^{6}$ Kapalı e /è/ ünlüsü üzerine yapılan araştırmalar için bkz.: R.R. ARAT, "Türkçe Metinlerde e/i Meselesine Dair", Makaleler I, TKAE, Ankara 1987, s. 334-341; Emine YILMAZ-CEYLAN, "Ana Türkçede Kapalı e Ünlüsü”, Türk Dilleri Araştırmaları 1991, Ankara 1991: 151-165; Timur KOCAOĞLU, “Tarihi Türk Lehçeleri Metinlerinin Transkripsiyonlanmasında Kapalı é/i Meselesi”, Türk Kültürü, Sayı: 483-484 (Temmuz-Ağustos 2003), s. 266-281; Orhan YAVUZ, "Türkçe'de 'Kapalı e’”, S.Ü. Fen-Edebiyat Fakültesi Edebiyat Dergisi, 6. Sayı, 1991: 271-306 ve başkaları.
} 
3.4

Diğer metinlerde rastlamadığımız bu husus müstensihten kaynaklı bir hata mıdır? bar- ve bèr- ile yat- ve yèt- kelimeleri arasında anlam açısından bir bağ bulunmadığını kaynaklarda "Uygur destan şairi” olarak tanımlanan Ömer Baki’nin bilmediği düşünülemez. İncelediğimiz metinler içinde en erken tarihli olan bu eserde azımsanmayacak kadar çok örnekte görülen bu hususiyet, Türkçenin dokuzuncu ünlüsü olması noktasında tartışma yaratan kapalı e sesinden kaynaklanmaktadır.

Eski Türkçeden itibaren varlığı bilinen kapalı e ünlüsünün Yenisey yazıtlarında özel bir işaretle gösterilmiş olması dolayısıyla Tekin, Orhun ve Yenisey yazıtlarındaki söz konusu ünlüyü taşıyan sözcükleri karşılaştırmalı olarak incelemiş, bu kapalı e ünlüsünün Orhun Türkçesinde uzun ve kısa biçimlerinin olduğunu vurgulamıştır. Uzun kapalı e'ye örnek olarak $b(e) r$ - "vermek", $b(e) s$ "5", (e)ki "2", (e)l "halk, boylar, devletler", (e)t- "yapmak, düzenlemek", $k(e) r \ddot{u ̈ ~ " g e r i ", ~} k(e)$ sre "sonra", $t(e)$ - "demek, söylemek", $t(e) r$ - "dermek, toplamak", $y(e)$ - "yemek", $y(e) t i$ "7", $y(e)$ tmis "70", idi [ēdi] "sahip", ir- [ēr-] "ermek, erişmek", irtür- "eriştirmek", kiçe [kēçe], y(e)t- [yêt-] "yedmek, yedekte götürmek", yil [yēl] "yele" kelimelerini vermiş ve Yenisey yazıtlarında özel kapalı /e/ harfi ile yazılan sözcüklerden eş [ēş], bel [bēll] ve keş [kēş] sözcüklerinin de bu gruba katılması gerektiğini belirtmiştir (Tekin 2000: 49). Tekin, ayrıca Borovkov tarafindan yayımlanan Anonim Kuran Tefsiri'nde beri sözcügündeki ünlünün de uzun kapalı e olduğunu ve bērü şeklinde tespit ettiğini bildirmiştir (Tekin 1995: 114). Bünyesinde uzun kapalı e ünlüsünü barındıran bèr-, yèt- ve béri sözcüklerinde tespit ettiğimiz bu elif'li yazma hususiyetinin söz konusu ünlünün imlada gösterilmesine ilişkin bir çaba olduğu kanaatindeyiz.

\subsection{Elif'li vav (و) yazımı:}

RS'de 42 kere geçen bol- kökü 20 kez بول şeklinde normal imlasılyla yazıllırken, 22 kez بول şeklinde yazılmıştır. Üzerinde çalışmalarımızın devam ettiği ZK'da bol-fiilinin بول بول ve ve dışında, ünlüsü gösterilmeden بل şeklinde olmak üzere üç farklı yazımına rastlamaktayız. RA'da 63 kere geçen bol- kökü 61 örnekte بول şeklinde normal imlasıyla yazılırken, 11b/3

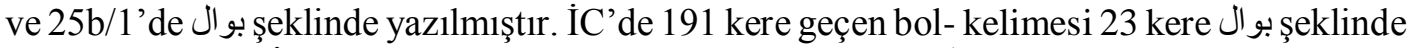
yazılmıştır. Yine İC'de 11 kere geçen tol-kelimesi bir yerde تو şeklinde yazılmıştır.

Kız Destanı ve Tevārih̆-i Fetḥ-i Rodos adlı eserlerde karşılaştığ bu hususiyeti "elifli vav" olarak adlandıran Ersoylu, Eski Türkiye Türkçesi Metinlerinde Kullanılan Elifli Vav isimli yazısında vav harfinin yanına yazılan elif'i, Eski Türkiye Türkçesi metinlerinde çok yaygın olarak kullanılan hareke işaretlerinin dışında yanına geldiği harfin ses değerini belirten bir harf olarak değerlendirmektedir (Ersoylu 2000: 135). Son sesi u veya ü ile biten Türkçe kelime tabanları ve Türkçe eklerde tespit ettiği bu yazımı, şekil olarak Arap yazı dilinde genel çokluk belirten u zamirinin yazlya geçirilişinde, onun bu niteliğini bildirici özel bir işaret olan elif'in, Eski Türkiye Türkçesi döneminde yazılan bazı metinlerde, sonu vav ile biten Türkçe kelime ve unsurlara da getirilmiş, yazıdaki biçim aktarması olarak açıklamaktadır (Ersoylu 2000: 137). Dolayısıyla Ersoylu, elifli vav yazımını sonu u ve ü ile biten kelimelerle sınırlamakla birlikte elif' in kendinden önce gelen vav harfini ünlü okutmak için kullanıldığını da belirtmiştir.

Ersoylu'dan önce XV. yy.1n ilk yarısında Abdülvasi Çelebi'nin yazdığı Halilname adlı mesnevide elifli vav kullanımına dikkat çektiğini bildiren Abik, bu yazımın sadece son sesteki u ve ü ünlülerini değil, bütün yuvarlak ünlüleri ve üç kelimede iç sesteki yuvarlak ünlü için de kullanıldığını ve vezin gereği uzunlukla açılanamayacağını bildirmiştir (Abik 1997: 148-149). Yine Kutadgu Bilig'in Mısır nüshasında rastladığı bu yazım özelliğini vezinle ilgili bir değere işaret etmediği gibi, eserde sıklığı azımsanmayacak kelimelerde kullanılması (bir kısmı -gu sıfat-fiil eki almış kelimeler, bir kısmı ötrü gibi edat, bir kısmı bögü, karagu gibi isim olan kelimeler) dolayısıyla 
da yazıcının vav'ın ünsüz olarak okunmasını engellemek için elif'i eklemesi şeklindeki Ersoylu'nun görüşünü reddetmektedir. (Abik 2007b: 27).

Kutadgu Bilig'in Mısır Nüshasının Yazım ve Dil Özelliklerine Göre Değerlendirilmesi adlı yazısında Karg1-Ölmez, bu yazımın Rabguzi'nin Klsasü'l-Enbiya'sının en eski olan ${ }^{7}$ ve dil özelliklerini yansıtan Londra nüshasında da bulunduğunu bildirir. Adı geçen eserlerin istinsah tarihlerini göz önünde tutarak elifli vav yazımının XIV. yüzyılın ikinci yarısı ile XV. yüzyılın başında hem Doğu hem de Batı Türkçesinde kullanıldığı sonucuna varır (K.-Ölmez 2014: 247). Ölmez, جو امرد Nehcü'l-Ferâdis'te bu yazıma rastlanmadığını belirtse de cömert kelimesinin geçtiği her yerde şeklinde yazıldığı görülmektedir.

Çalışmamıza konu olan metinlerde bol-ve bir kez de tol-kelimesinde rastladığımız bu yazım özelliği, Ersoylu'nun ifade ettiği gibi sonu u ve ü ile biten kelimelerde görülmemektedir. XIV. yüzyıldan itibaren hem Doğu sahası hem de Batı sahası eserlerinde görülen bu yazım özelliği, çağdaş lehçelerde (Türkmence, Nijniy Novgorod Tatar Ağzı) ve tarihi lehçelerde (DLT, Kitabu'l-İdrak) bōlşeklinde tespit edilen, Yakutçada da buol-şeklinde varlık gösteren uzun ünlünün konuşma dilindeki bir kalıntısı olarak imlaya yansıması olarak değerlendirebiliriz.

Ana Türkçedeki birincil uzun ünlülerin kendilerini düzenli bir şekilde Yakutça ve Türkmence'de koruduğunu, öbür Türk dil ve lehçelerinde genel olarak kısalmış ve kısa ünlülerle karışmış olduğunu belirten Tekin, "birincil uzun ünlülerin klsaldığı birçok dil, lehçe ve ağızda, düzensiz ve dağını bir şekilde de olsa, birincil uzunlukların kalıntısına rastlamaktayız” dedikten sonra siraladığı bu dil, lehçe ve ağızlar arasında Yeni Uygurca (Kaşgar, Turfan vb. ağızlar) ve Özbekçe (Hive, Buhara lehçeleri, Türkmenceleşmiş Harezm ağızları, Kongrat ve Kattagan lehçeleri)'yi de göstermiştir (Tekin 1995: 38).

\section{Sonuc}

Dil tarihinde zaman ve saha ayrımını belirleyecek ölçütler oluşturma çabaları, Klasik sonrası Doğu Türk yazı dili için, eserlerin tam olarak ortaya çıkarılmaması nedeniyle zayıf kalmıştır. Farklı yüzyıllarda ama ortak bir coğrafyada ve ortak yazı diliyle yazılmış olan eserler üzerinden yazımda klasik Doğu Türkçesinden ayrılan yönleri belirlemeye çalıştık. XX. yüzyıla kadar Türk dünyasının doğu kanadında ortak yazı dili olarak varlık gösteren Doğu Türkçesi ile, farklı Türk boylarının ağız özelliklerini söz varlığı, ses ve biçim bilgisi yanı sıra imlada da göstermeye başladığı eserler verilmiştir. İmladaki mahallileşme eğilimleri, Doğu Türk yazı dilinin tek yazı dili olma durumundan çıkarak yeni yazı dilleri oluşma sürecinde konuşma dilinin yazıma aksettirilmesini göstermesi bakımından önemlidir. Alıntı kelimelerde normal uzunluktaki ünlülerin gösterilmesi hususiyetini Türk yazım geleneğine yaklaşma eğilimi olarak, yine alıntı kelimelerde uzun ünlünün yazılmaması hususiyetini ise, ağız özelliğinin yazıma aksettirilmesi olarak değerlendirdik. Bèr-, yèt- ve béri kelimelerindeki elif'li yazımlar ile bol- ve tol- kelimelerindeki elifli vav yazımını asli ünlü uzunluklarının imlada gösterilme çabası olduğu yönündeki fikrimizi bildirdik. Ortaya çıkarılacak yeni eserler ve elimizde olan eserlere bu açıdan yaklaşılarak yapılacak çalışmalar konu ile ilgili ciddi bir malzeme sunacaktır.

\footnotetext{
${ }^{7}$ H.E. Boeschoten, Londra nüshasından daha sonra keşfedilen Tahran nüshasının Londra nüshasıyla aynı yaşta ya da daha eski olduğunu belirtmektedir: "Although numerous manuscripts of the Qișaș-ï Rabgūzī have been pre-served, there are no really old ones among them. As in the case of the first edition, the manuscript kept in the British Library (referred to as ms.A below) has served as the basis for the present edition.It was produced at least a century and a half after Rabgūzī had completed his work. The only other manuscript that may be of the same age or older is the one from the Tehran UniversityLibrary. The other three manuscripts used for this edition must be dated even later. Unfortunately, we have not been given the opportunity to consult the two oldest Tashkent manuscripts, and we are not sure about their age." (Boeschoten 2015: XX-XXI).
} 


\section{KISALTMALAR VE KAYNAKLAR}

Abik 1997

Abik, Deniz (1997), "İki Yeni Nüshası Sebebiyle Halilname ve Müellifi Abdülvasi Üzerine”, Türkoloji C. XII, S. 1, s. 139-175.

Abik 2007a Abik, Deniz (2007), "Sufî Allahyâr ve Sebâtü'l-Âcizîn'i: 18. Yüzy1l Doğu Türk Edebî Dilinde Mahallîleşme Eğilimleri”, International Journal of Central Asian Studies, Vol 11-1, s. 52-73.

Abik 2007b

Abik, Deniz (2007), "Kutadgu Bilig'in Mısır Nüshasında İki Yazım Özelliği", Doğumunun 990. Yılında Yusuf Has Hacib ve Eseri Kutadgu Bilig, 26-27 Ekim, Vol. 1, İstanbul 15-20.

Boeschoten 2015 Boeschoten, H.E.- O'Kane, J. (2015), Al-Rabghūzī The Stories of the Prophets, Qișaș al-Anbiyā' ': An Eastern Turkish Version (Second Edition), Vol. I- Text Edition, Brill, Lieden/Boston.

Canpolat 1995 Canpolat, Mustafa (1995), Ali Şir Nevayî - Lisânü’ṭ-țayr, Ankara.

Çelik 2012 Çelik, M. Bilal (2012), "Saidiye Hanlığı ve Hocalar Devri Kaynakları (15141762)", History Studies, Vol. 4, Issue 4, p. 65-89.

Eckmann 1964 Eckmann, J. (1964), “Çağatay Edebiyatının Son Devri (1800-1920)”, TDAYBelleten 1963, s. 121-156.

Ersoylu 2000 Ersoylu, Halil (2000), "Eski Türkiye Türkçesi Metinlerinde Kullanılan Elifli Vav", Hasan Eren Armağanı, TDK Yay. 773, Ankara, s. 135-139.

FŞ

Bakırcı, Fatih (2016), Ömer Baki, Hamse-i Nevayî I: Ferhad ü Şirin, Kesit Yayınları, İstanbul.

K.-Ölmez 1996 Karg1-Ölmez, Zühal (1996), Ebulgazi Bahadır Han Şecere-i Terâkime (Türkmenlerin Soykütüğü), Ankara: Simurg Türk Dilleri Araştırmaları Dizisi: 3.

K.-Ölmez 2014 Kargı-Ölmez, Zühal (2014), “Kutadgu Bilig'in Mısır Nüshasının Yazım ve Dil Özelliklerine Göre Değerlendirilmesi”, VIII. Milletlerarası Türkoloji Kongresi 30 Eylül- 04 Ekim 2013, Bildiri Kitabı II, İstanbul, s. 241-254.

LM Alper, Serap (2016), Ömer Baki, Hamse-i Nevayî II: Leylî vü Mecnun, Kesit Yayınları, İstanbul.

RA Alper, Serap (2017), Risale-i Aşfezlik (Aşçılık Risalesi), TEKE Uluslar arası Türkçe Edebiyat Kültür Eğitim Dergisi, Cilt:6, Say1: 4, s. 2027-2066.

RK

Alper, Serap (2017), "Risale-i Kaçacılık (Çömlekçilik Risalesi)", Türkiyat Mecmuası, Cilt: 27/1, 15-32.

RS

Alper, Serap (2016), "Risâle-i Sâbûn-gerlik”, Marmara Türkiyat Araştırmaları Dergisi, Cilt III, Sayı I, 45-69.

Seyhan 2004 Oral-Seyhan, Tanju, "Orta Türkçede Arapça ve Farsçadan Alıntılarda Türkçeleştirme”, V. Uluslar arası Türk Dili Kurultayı Bildirileri 20-26 Eylül 2004, C.I, TDK Yay., Ankara.

Tekin 1995 Tekin, Talat (1995), Türk Dillerinde Birincil Uzun Ünlüler, Türk Dilleri Araştırmaları Dizisi: 13, Ankara. 
Tekin 2000 Tekin, Talat (2000), Orhon Türkçesi Grameri, Türk Dilleri Araştırmaları Dizisi:9, Ankara.

ZK Ziyaü'l-Kulûb, yayıma hazırlanmaktadır. 